\title{
Awareness of Students' Emotional and Behavioral Screening Test based on Parental and Teacher Ratings
}

\author{
In Tae Kim¹, Eun Ju Bang ${ }^{2}$, Ga Gyung Kim¹, and Hyun Ju Hong ${ }^{1,3}$ \\ ${ }^{1}$ Department of Psychiatry, Hallym University Sacred Heart Hospital, Anyang, Korea \\ ${ }^{2}$ Department of Psychology, Sungkyunkwan University, Seoul, Korea \\ ${ }^{3}$ Suicide and School Mental Health Institute, Anyang, Korea
}

\author{
부모와 교사의 평정에 기반한 학생정서 - 행동특성검사에 대한 인식 조사 \\ 김인태 ${ }^{1}$, 방은주 $^{2}$, 김가경 $^{1}$, 홍현주 $^{1,3}$ \\ 한림대학교 성심병원 정신건강의학과, ${ }^{1}$ 성균관대학교 심리학과, ${ }^{2}$ 자살과 학생정신건강연구소 ${ }^{3}$
}

Objectives: Since 2013, the Students' Emotional and Behavioral Screening Test (SEBT) has been conducted annually for 1st grade and 4th grade elementary school students, 1st year middle school students, and 1st year high school students. The SEBT has been considered to have effectiveness and strength for screening high risk students who have a strong possibility of harboring emotional or behavioral problems in school. Therefore, in this study, we conducted an investigation into the awareness of the SEBT based on the rating score of the parents and teachers to determine its future direction and management.

Methods: A total of 731 parents and 149 teachers participated in this study. Each participant completed a self-administered questionnaire on their awareness of the SEBT.

Results: 428 (58.5\%) parents and 99 (66.4\%) teachers rated their overall satisfaction at more than 4 points out of a total of 5 points. The test reliability was rated at more than 4 points out of a total of 5 points by $52.1 \%$ of the parents $(n=381)$ and $47.7 \%$ of the teachers ( $n=71)$.

Conclusion: Both parents and teachers consider the SEBT to be highly satisfactory and reliable.

Key Words: Student health services; Mental health; Personal satisfaction; Surveys and questionnaires.

Received: June 14, 2017 / Revision: August 8, 2017 / Accepted: September 12, 2017

Address for correspondence: Hyun Ju Hong, Department of Psychiatry, Hallym University Sacred Heart Hospital, 14 Gwanpyeong-ro 176beon-gil, Dongangu, Anyang 14068, Korea

Tel: +82-31-380-6012, Fax: +82-31-380-6013, E-mail: honghj88@gmail.com

서 론

2014년 발표된 세계보건기구(World Health Organization) 보고에 따르면 2010년대 들어서 소아청소년의 정신건강은 큰 부분을 차지하는 문제로 부각되고 있다. 특히 세계적으로 자 살은 소아청소년의 사망원인 가운데 3위를 차지하고 있고, 우 울증은 질병 및 장애의 가장 큰 원인으로 지목되고 있다. 정 신건강 장애의 절반 정도는 14 세에 시작되고 있지만 대부분 의 경우는 인식되지 않고 치료되지 않은 채로 지나가고 있으 며, 이는 생애 전반에 심각한 정신건강 문제를 야기하고 있다. ${ }^{1)}$ 한편 우리나라 소아청소년의 자살은 사망원인 가운데 1 위를

This is an Open Access article distributed under the terms of the Creative Commons Attribution Non-Commercial License (http://creativecommons.org/licenses/by-nc/4.0) which permits unrestricted non-commercial use, distribution, and reproduction in any medium, provided the original work is properly cited.
차지하고 있고, ${ }^{2)}$ 이와 관련된 우울감 경험률(25.5\%)과 자살 시 도율(2.4\%)은 간과할 수 없는 수준이며, ${ }^{3)}$ 소아청소년의 8 10\% 가 정신의학적 진단이 가능할 정도로 정신건강 문제가 심각한 것으로 추정되고 있다." 이러한 상황에 맞추어 소아청소년, 즉 학생의 정신건강 문제에 대한 국가적인 정책의 필요성도 높아 지고 있다.

우리나라는 2006년 학교보건법이 개정되어 정신건강이 강 조된 이래로 교육부가 2007년도부터 학교보건법 및 교육기본 법에 따라 정신건강 문제의 조기 발견 및 악화 방지를 목적으 로 학생정서·행동특성검사를 실시해 오고 있다. 2012년도에 는 학교폭력문제가 가시화되면서 전국의 전체 학생을 대상으 로 전수조사가 실시되기도 했다. 2013년 이후에는 학생정서. 행동특성검사의 온라인조사 체계가 마련되어 검사방식이 간 소화되었으며 이에 따라 매년 초등학교 1, 4학년, 중학교 1학 
년, 고등학교 1학년을 대상으로 정례화되어 실시되고 있다. 또 한 학생정서·행동특성검사로 선별된 정신건강 고위험군은 '관심군'으로 정의되며 2013년부터 교육청 차원에서의 관심군 지원체계 구축을 위한 학생정신건강 지역협력모델 구축 지원 사업도 시작되면서 학교를 중심으로 지역사회와의 연계 협력 이 활발해졌다. ${ }^{5)}$

학생정서·행동특성검사는 초등학교 1, 4학년의 경우 부모의 평가로 아동 문제행동 선별질문지(Child Problem-Behavior Screening Questionnaire, CPSQ) 척도를 활용하여 실시되어 오고 있으며 중·고등학교 1학년생의 경우 청소년 정신건강 및 문제행동 선별질문지(Adolescent Mental Health ProblemBehavior Questionnaire-II, AMPQ-II) ${ }^{78}$ 척도가 자가 평가로 실시된다. $\mathrm{CPSQ}$ 와 $\mathrm{AMPQ}-\mathrm{II}$ 는 아동·청소년의 전반적인 정 신병리를 평가하는 척도로 구성되어 있다. 이 검사의 시행 이 후 학생들의 전반적인 정신건강에 대한 평가가 가능해졌으며 학교에서는 관심군으로 분류된 학생들에 대한 관심과 지원이 향상되었고 관심군 학생의 지역사회 전문기관 연계율이 증가 하였다. ${ }^{5)}$ 그러나 지속적으로 시행되어 오고 있는 학생정서·행 동특성검사에 대한 인식 조사는 활발하지 못한 실정이며, 특 히 선별된 학생에 대한 관리와 연계에 있어 중요한 역할을 하 는 부모와 교사의 인식을 살펴본 연구는 찾아보기 힘들다.

이에 본 연구에서는 부모와 교사의 학생정서-행동특성검사 에 대한 인식의 차이를 파악하고 향후 보다 효율적인 학생정 서-행동특성검사를 시행하는 데 있어 도움이 될 수 있는 기초 자료를 제공하고자 한다.

\section{방 법}

\section{대 상}

본 연구의 대상은 2014 학생정신건강 지역협력모델 구축지원 사업 참여 학교 중에서 학교 급별 남녀 비율을 고려하여 선정하였다. 이에 전국 총 79 개 초·중·고등학교(초등학교 24 개교, 중학교 30개교, 고등학교 25개교)에 재학 중인 2014년 도 기준 초등학교 1, 4학년, 중학교 1학년, 고등학교 1학년 학 생 중 2014년 학생정서·행동특성검사에 참여한 학생의 부모 와 교사가 일차 대상자였다. 연구 대상의 모집과 연구 진행과 정은 자살과 학생정신건강연구소가 교육부의 협조를 얻어 이 루어졌으며 진행과정은 다음과 같다. 먼저 교육부를 통해서 해당학교에 협조 공문을 발송 후 연구자가 대상학교의 행정 책임자 및 담당교사에게 연구내용을 설명하고 연구참여에 동 의한 경우에 부모와 교사에게 설문을 진행하였다. 설문지는 부모용과 교사용의 버전으로 만들어졌으며 교사집단의 일차 대상자 산정은 한 학년의 담임교사와 상담교사, 보건교사의
수를 학교당 약 10 명으로 가정하였다. 이에 총 18180 명의 부모 와 1030 명의 교사가 일차 설문 대상으로 추정되었으나 실제로 연구에 동의하고 조사에 참여한 경우는 부모 집단에서 869부, 교사 집단에서 224 부였다. 이 중 불성실 응답으로 각각 138 부, 75 부를 삭제한 후 부모집단은 731부, 교사 집단은 149 부가 최 종분석대상이었다(Fig. 1).

이 중 부모 집단에서 관심군으로 통보 받은 35 명을 대상으 로 관심군에 대한 추가적인 설문을 하였고 그 결과 불성실 응 답(3부)을 제외하고 32부의 설문이 수집되었고 이를 분석 대상 에 포함하였다.

본 연구는 한림대학교 성심병원 임상시험심사위원회(IRB)의 승인을 거쳤다(IRB No. 2015-I014).

\section{도구 및 방법}

자살과 학생정신건강연구소는 학생정서·행동특성검사의 주요 수요자인 부모와 교사들이 생각하는 학생정서·행동특 성검사의 전반적인 성과 및 만족도, 관심군 학생 관리의 현황 과 만족도를 평가하기 위한 자체 설문도구를 개발하였다. 부 모와 교사 설문지에는 공통적으로 포함되는 항목과 함께 두 집단의 특성을 반영한 다른 항목도 포함되었다. 부모 대상 설 문내용은 학생정서-행동특성검사에 대한 전반적인 인식도, 성과 및 만족도를 묻기 위한 15 개 문항과 학생정서·행동특성 검사 관심군 개입에 대한 인식도, 성과 및 만족도를 묻기 위한 17 개의 문항으로 구성되었다. 한편 교사 대상의 설문내용은 학생정서·행동특성검사에 대한 전반적인 인식도, 성과 및 만 족도를 묻기 위한 것은 15 개 문항으로 이루어졌지만 관심군 개입에 대한 전반적인 인식 및 만족도에 대한 것은 6 개 문항 으로 구성되었다.

연구 대상자들은 2015년 3월 9일부터 4월 17일까지 '자살 과 학생정신건강연구소 홈페이지에 온라인으로 구축된 시스 템을 통해 동의서를 작성하고 설문조사에 참여하였다. 연구 참여는 1 회에 종결되었으며 설문조사를 작성하는 시간은 약 10 분 정도 소요되었다.

본 연구에서는 학생정서·행동특성검사에 대한 전반적인 인 식도, 성과 및 만족도에 관한 15 개 문항 중 부모와 교사 두 집 단의 비교를 위해서 양측 모두 공통으로 해당되는 14 개 문항 을 분석하였다. 또한 관심군 학생의 부모를 대상으로 한 관심 군 개입에 대한 문항 17 개 중 통계적으로 의미를 확인해 볼 수 있는 9 개 문항에 대해서 분석하였다.

\section{통계 분석}

부모 및 교사 설문지를 통한 학생들의 정신건강에 대한 인 식도와 개입방향, 학생정서·행동특성검사의 성과 및 만족도 


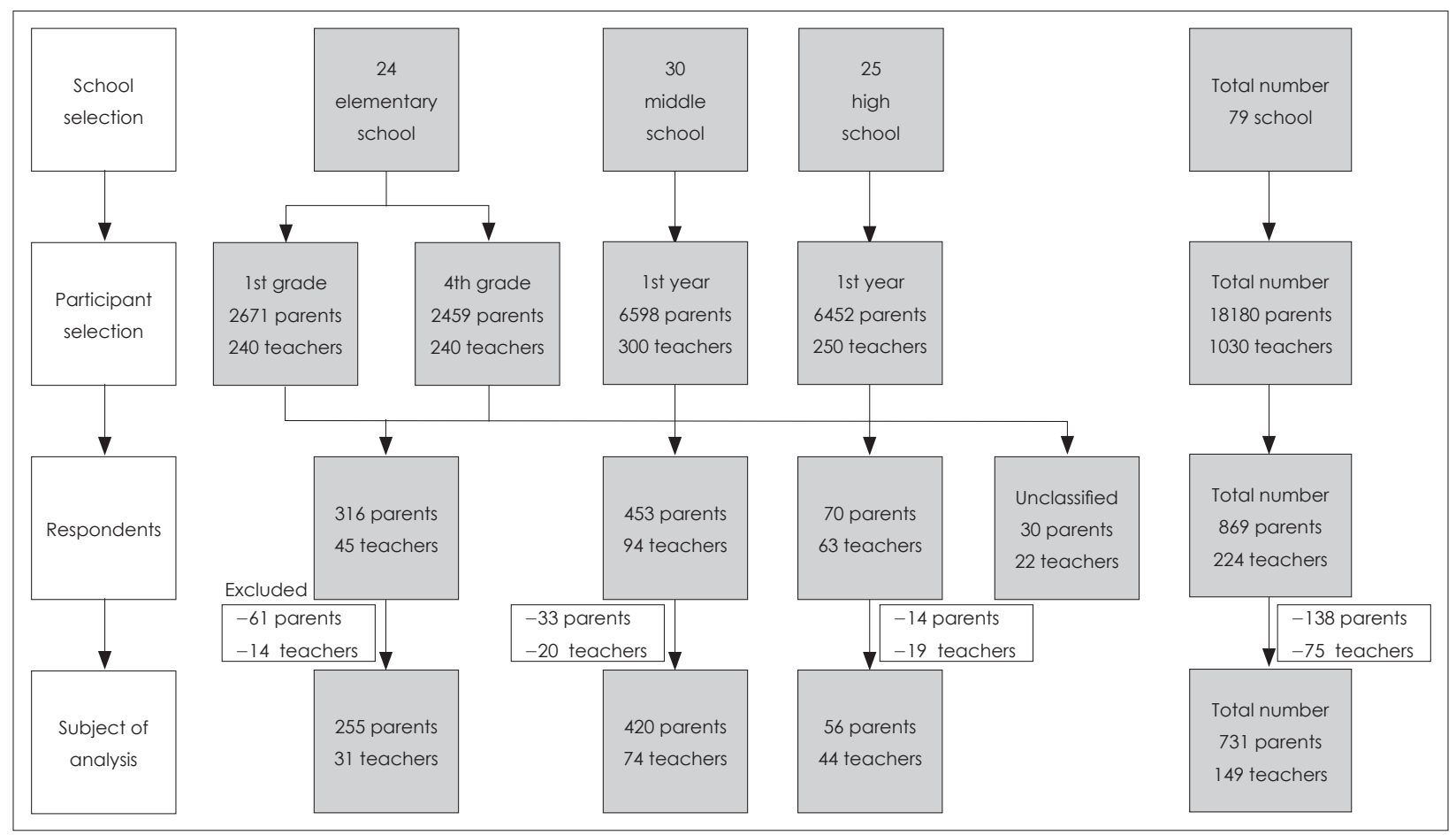

Fig. 1. Participants in investigation for satisfaction about Students' Emotional and Behavioral Screening Test.

에 대해서 기술통계를 시행하였다. 부모 및 교사의 인식도에 대 한 차이를 살펴보기 위해서는 선정된 14 개의 문항 중에서 9 개 문항은 리커트 5점 척도의 총점을 기준으로 독립표본 $\mathrm{t}$-검정 을 시행하였다. 또한 4점 이상인 군은 명목변인으로 재분류하 여 이 군에 대한 빈도분석(\%, 백분율)과 카이제곱 검정을 통해 서 두 집단의 차이를 분석하였다. 나머지 5 개 문항에 대해서는 답변에 대한 빈도분석(\%, 백분율)만을 통해서 집단의 특성을 확인하였다.

관심군 개입과 관련된 9개 문항에 대해서는 빈도분석을 통 해서 경향성을 확인하였다. 통계 유의 수준은 0.05 로 하였으며 통계 분석에는 윈도우용 SPSS ver. 21(IBM Corp., Armonk, $\mathrm{NY}, \mathrm{USA}$ )을 사용하였다.

\section{결 과}

부모 집단을 보면 대다수가 여성으로 624명(85.4\%)이고 중 학생의 부모가 420명(57.4\%)으로 가장 많으며 대도시 학교 소 속이 539명(73.7\%)이다. 교사 집단을 보면 대다수가 여성으로 124 명(83.2\%)이고, 교사의 지위 분류에서는 양호, 상담, 일반, 기타 교사들 중 일반교사가 77 명 (51.6\%)으로 가장 많고, 학교 급별 교사 분류에서는 초, 중, 고 교사들 중 중학교 교사가 74 명(49.7\%)으로 절반 수준이며, 대도시 학교 소속이 88명(59.1\%) 으로 가장 많은 비중을 차지한다(Table 1).
Table 1. Demographic characteristics of respondents

\begin{tabular}{lcc}
\hline \multicolumn{1}{c}{ Classification } & $\begin{array}{c}\text { Number } \\
\text { of parents (\%) }\end{array}$ & $\begin{array}{c}\text { Number } \\
\text { of teachers (\%) }\end{array}$ \\
\hline $\begin{array}{l}\text { Gender } \\
\text { Male }\end{array}$ & $107(14.6)$ & $25(16.8)$ \\
$\begin{array}{l}\text { Female } \\
\text { Position in school }\end{array}$ & $624(85.4)$ & $124(83.2)$ \\
Nurse teacher & - & $33(22.1)$ \\
Counseling teacher & - & $24(16.1)$ \\
General teacher & - & $77(51.6)$ \\
Others & - & $15(10.1)$ \\
Level of school & & $31(20.8)$ \\
Elementary school & $255(34.9)$ & $74(49.7)$ \\
Middle school & $420(57.4)$ & $44(29.5)$ \\
High school & $56(7.7)$ & $88(59.1)$ \\
Regions & & $61(40.9)$ \\
Big city & $539(73.7)$ & $149(100)$ \\
Small city & $192(26.3)$ & \\
Total & $731(100)$ &
\end{tabular}

부모 집단과 교사 집단을 비교한 내용은 Table 2에 정리되어 있다. 본 연구에서는 $\mathrm{t}$-검정을 통한 분석을 할 때 리커트 5 점 척도 $(1,2,3,4$, or 5$)$ 의 각 문항에 대한 평균점수를 비교하였 으며 각 문항은 동의 수준이 가장 높은 경우가 5점(매우 우수, 매우 만족, 매우 그렇다, 매우 심각하다)이고, 동의 수준이 가장 낮은 경우를 1점(매우 부족, 매우 불만족, 전혀 그렇지 않다, 전 


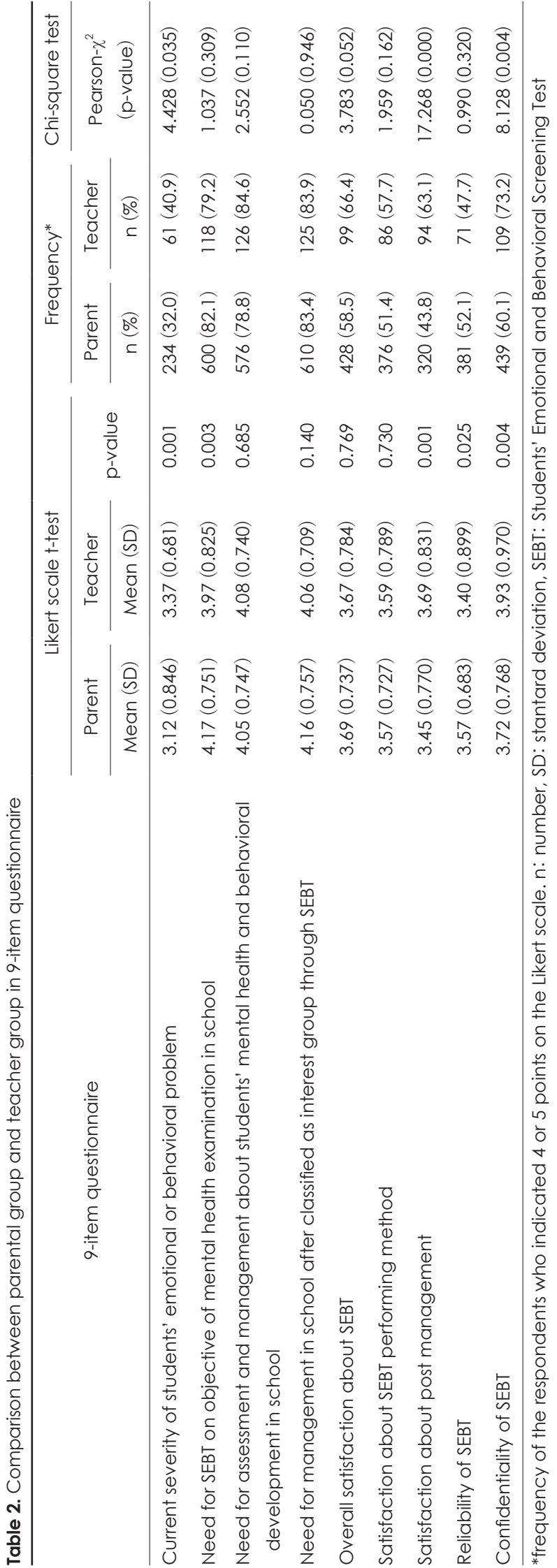

혀 심각하지 않다)으로 설정했다. 빈도분석에서는 각 문항에 대 해서 4점 이상으로 표시한 것의 빈도수와 백분율(\%)을 확인 하였고 두 집단을 비교한 카이제곱 검정 값을 계산하였다.

현재 학생들의 정서·행동적 문제의 정도를 묻는 문항은 차 이를 보였는데, 부모는 평균 3.12점, 교사는 평균 3.37점으로 교사에서 더욱 높게 나오고 있고, 이 차이는 통계적 유의성( $\mathrm{p}$ $<0.05)$ 이 있다. 빈도분석에서도 부모의 $32.0 \%(\mathrm{n}=234)$ 보다 교 사의 $40.9 \%(\mathrm{n}=61)$ 가 더욱 높고 이 차이는 카이제곱 검정에서 도 통계적으로 유의미한 차이가 있다 $\left(\chi^{2}=4.428, \mathrm{p}<0.05\right)$ 는 것 을 볼 수 있는데, 부모보다 교사가 학생들의 문제를 더욱 심각 하게 여긴다는 것을 알 수 있다.

학교에서 학생들의 정신건강 검진을 목적으로 하는 학생정 서·행동특성검사가 필요한지를 묻는 문항에서 리커트 척도 점수의 평균은 부모 4.17점, 교사 3.97점으로 이는 통계적인 유의성 $(\mathrm{p}<0.05)$ 을 갖는 점수 차이다. 빈도분석에서도 부모 $82.1 \%(\mathrm{n}=600)$, 교사 $79.2 \%(\mathrm{n}=118)$ 를 보였으나 카이제곱 검정 값 에서는 통계적으로 유의미한 차이가 없었으며 $\left(\chi^{2}=1.037, \mathrm{p}>\right.$ 0.05), 평균적으로 부모가 교사보다 학생정서-행동특성검사의 필요성을 높게 평가하였다. 학교에서 학생들의 정신건강 및 행동발달에 대한 평가와 관리가 이루어질 필요성을 묻는 항목 에 대한 빈도분석을 보면 부모는 $78.8 \%(\mathrm{n}=576)$, 교사는 $84.6 \%(n=126)$ 로 높게 보고되고 있으며 두 군 간의 차이는 보이지 않았다(부모 평균 $=4.05$ 점, 교사 평균 $=4.08$ 점, $\mathrm{p}>$ 0.05). 또한 관심군에 대한 관리 필요성 항목 역시 부모는 83.4\% $(\mathrm{n}=610)$, 교사는 83.9\%( $\mathrm{n}=125)$ 로 두 집단 모두 필요성 을 높게 평가하고 있었으며 두 군 간의 차이는 보이지 않았다 (부모 평균 $=4.16$ 점, 교사 평균 $=4.06$ 점 $\mathrm{p}>0.05$ ).

학생정서-행동특성검사에 대한 전반적인 만족도를 묻는 문항에서는 부모의 $58.5 \%(\mathrm{n}=428)$, 교사의 $66.4 \%(\mathrm{n}=99)$ 가 '필 요하다를 의미하는 4점 이상으로 답변하였다. 학생정서-행동 특성검사의 시행방식에 대한 만족도 문항에서는 부모 $51.4 \%$ $(n=376)$, 교사 $57.7 \%(n=86)$ 가 4점 이상의 만족도를 보였다. 학 생정서-행동특성검사 시행 이후 사후 도움에 대한 만족도 항목 의 평균점수는 부모 3.45점, 교사 3.69점으로 두 군 모두 비교 적 만족하였으나 통계적으로는 두 군 간의 차이를 보였다 $(\mathrm{p}<$ 0.05). 빈도분석에서도 부모의 $43.8 \%(\mathrm{n}=320)$, 교사의 $63.1 \%$ $(\mathrm{n}=94)$ 가 4점 이상으로 답변하였고, 카이제곱 검정에서도 통 계적으로 유의미한 차이가 있었다 $\left(\chi^{2}=17.268, \mathrm{p}<0.05\right)$. 전반적 으로 부모보다 교사가 사후 도움에 대한 만족도가 높은 것을 알 수 있다.

학생정서-행동특성검사의 신뢰도를 묻는 문항에서 리커트 척도 점수의 평균이 부모 3.57점, 교사 3.40점으로 차이를 보 이고 이는 통계적인 유의성 $(\mathrm{p}<0.05)$ 을 보였다. 또한 빈도분석에 
서도 부모의 $52.1 \%(\mathrm{n}=381)$, 교사의 $47.7 \%(\mathrm{n}=71)$ 가 4 점 이상으 로 응답을 하여 전반적으로 부모가 교사보다 더 높은 수준의 신뢰도를 나타났으나 카이제곱 검정에서는 통계적인 유의성 을 보이지 않았다 $\left(\chi^{2}=0.990, \mathrm{p}>0.05\right)$. 학생정서·행동특성검 사 결과의 비밀 엄수 정도를 묻는 문항의 평균이 부모는 3.72 점, 교사는 3.93점으로 통계적 유의성을 갖는 차이를 보였다 $(\mathrm{p}<0.05)$. 빈도분석에서도 부모는 $60.1 \%(\mathrm{n}=439)$, 교사는 $73.2 \%(\mathrm{n}=109)$ 로 차이를 보였고, 카이제곱 검정에서도 통계적 으로 유의미한 차이를 보였다 $\left(\chi^{2}=8.128, p<0.05\right)$. 비밀 엄수에 대해서는 전반적으로 부모보다 교사에서 더 높게 나타났다.

학생정서·행동특성검사의 성과에 대한 문항에서 상위 3 개 응답을 살펴보면 부모는 1) 아동·청소년기 정신건강 관리의 중 요성에 대해 인식하게 되었다(26.4\%), 2) 아이의 정서·행동 문 제에 대한 관심이 증가했다(23.1\%), 3) 아이의 정서-행동적 상 태에 대해 알게 되었다(19.2\%) 등의 순으로 응답하였고, 교사 는 1) 학생의 정서·행동 문제에 관심이 증가 했다(19.0\%), 2) 학 생정서·행동특성검사를 통해서 학생의 문제를 조기 발견할 수 있다(18.3\%), 3) 학생의 정서-행동적 상태에 대해 알게 되 었다(17.9\%) 등의 순으로 응답하였다.

학생정서·행동특성검사의 보완점에 대한 문항에서 상위 3 개 응답을 살펴보면 부모는 1) 검사 안내 및 검사 결과에 대한 설명이 부족하다(19.2\%), 2) 검사 이후에 학교 내에서 학생에 대 한 정신건강 문제가 관리되어야 한다(17.9\%), 3) 고위험군 학생 에 대한 의무화된 사후관리가 필요하다(16.9\%) 등의 순으로 응
답하였고, 교사는 1) 외부 전문기관과의 연계가 원활하지 않다 (14.1\%). 2) 고위험군 학생에 대한 의무화된 사후관리가 필요하 다(12.8\%). 3) 충분한 수의 담당인력이 확보되어야 한다(12.3\%) 등의 순으로 응답하였다. 부모는 학교 내에서 학생들의 정신건 강 문제가 관리되기를 희망하나 교사는 학교 외부 전문가를 통해서 학생들의 정신건강 문제가 관리되기를 희망하는 점에 서 차이를 보였다.

학생정서·행동특성검사에서 평가해야 할 정서행동적 문제 (Fig. 2)에 대한 문항에서 부모는 공격행동, 품행문제와 같은 행동문제(33.0\%), 사회성(또래관계) 발달(31.6\%), 우울, 불안 등 과 같은 감정문제(17.1\%), 인터넷 중독(11.2\%), 자살(6.0\%), 기타 (1.1\%) 순으로 응답하였고, 교사는 우울, 불안 등과 같은 감정 문제(36.9\%), 공격행동, 품행문제와 같은 행동문제(30.2\%), 자 살(14.1\%) 및 사회성(또래관계) 발달(13.4\%), 인터넷 발달(3.4\%), 기타 $(2.0 \%)$ 순으로 응답하였다. 부모는 주로 행동이나 사회성 과 같은 영역에 관심을 갖고 있고 교사는 주로 감정 및 행동 영 역에 대한 관심이 높았다. 특히 감정적인 영역에 있어서 관심 의 차이가 두드러졌다.

학교에서 관심군 대상으로 어떠한 도움을 주어야 할지를 묻 는 문항에서 부모는 담임교사의 관심과 상담(34.2\%), 외부 전문 기관 의뢰(25.9\%), 외부 전문가에 의한 학교 내 프로그램 운영 (25.2\%) 등의 순으로 응답하였고, 교사는 외부 전문기관 의뢰 (35.6\%), 외부 전문가에 의한 학교 내 프로그램 운영(32.2\%), 보건교사, 상담교사와의 상담강화 $(17.4 \%)$ 등의 순으로 응답하
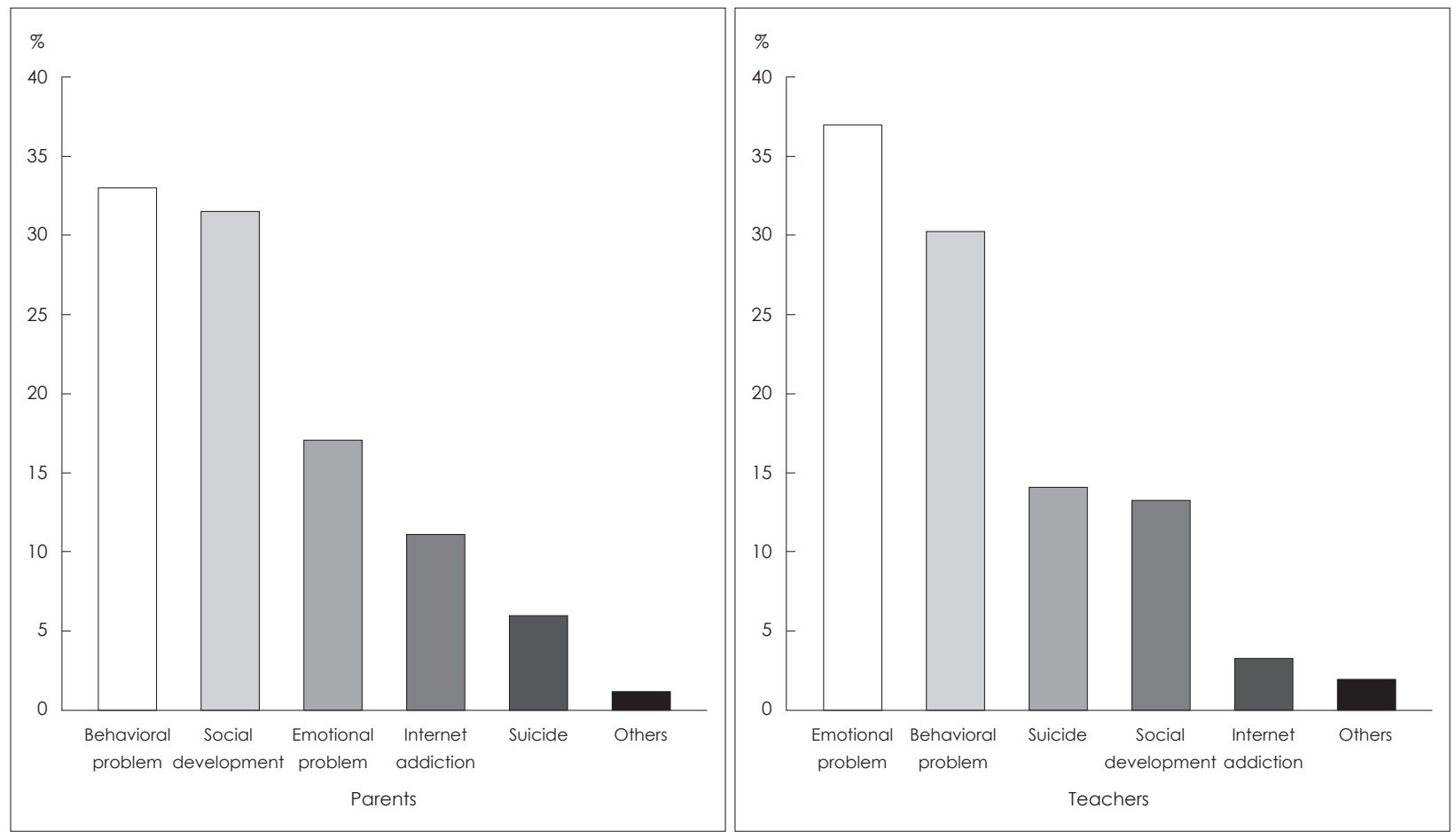

Fig. 2. Problems need to be evaluated through Students' Emotional and Behavioral Screening Test. 
였다. 부모는 관심군에 대한 도움을 위해서 교사의 역할을 더 욱 원하고 있고, 교사들은 관심군에 대한 도움을 외부 전문기 관이나 전문가의 역할로 보고 있어 차이를 보였다.

학생정서-행동특성검사 시행 사실에 대한 인지 정도는 부모 $80.9 \%$, 교사 $98 \%$ 가 인지한다고 응답하였고 대다수는 학생정 서-행동특성검사가 시행되고 있다는 것을 인지하고 있었지만 검사 실시에 대해서 상대적으로 부모의 인지가 교사보다 다소 부족한 것으로 볼 수 있다.

관심군 학생의 부모만을 대상으로 한 조사는 다음과 같다. 관심군 도움에 대한 전반적인 만족도를 묻는 문항을 보면 매 우 만족 9.4\% $(\mathrm{n}=3)$, 대체로 만족 $37.5 \%(\mathrm{n}=12)$, 보통이다 $43.8 \%$ $(\mathrm{n}=14)$, 대체로 불만족 $6.3 \%(\mathrm{n}=2)$, 매우 불만족 $3.1 \%(\mathrm{n}=1)$ 였 다. 검사 실시 이후 관심군 도움에 대한 만족도 문항에서 매 우 만족 3.1\%(n=1), 만족 31.3\%(n=10), 보통 56.3\%(n=18), 도움 못 받음 $9.4 \%(\mathrm{n}=3)$ 로 응답자 중 불만족 의견은 없었다. 학교 내 관심군 서비스에 대한 만족도를 묻는 문항에서는 매우 만 족 9.4\% $(\mathrm{n}=3)$, 만족 $37.5 \%(\mathrm{n}=12)$, 보통 $43.8 \%(\mathrm{n}=14)$, 매우 부족 $3.1 \%(\mathrm{n}=1)$, 도움 못 받음 $6.3 \%(\mathrm{n}=2)$ 였다. 관심군 학교 외부기 관 연계 서비스 만족도에 대해서는 매우 만족 $9.4 \%(n=3)$, 만 족 $18.8 \%(\mathrm{n}=6)$, 보통 $53.1 \%(\mathrm{n}=17)$, 부족 $6.3 \%(\mathrm{n}=2)$, 도움 못 받음 $12.5 \%(\mathrm{n}=4)$ 로 확인되었다. 관심군에서 학생정서 - 행동특 성검사 성과 정도를 묻는 문항에서 매우 동의한다 $12.5 \%(\mathrm{n}=4)$, 약간 동의한다 $34.4 \%(\mathrm{n}=11)$, 보통이다 $43.8 \%(\mathrm{n}=14)$ 약간 동의 하지 않는다 $6.3 \%(\mathrm{n}=2)$, 매우 동의하지 않는다 $3.1 \%(\mathrm{n}=1)$ 였 다. 관심군 안내 이후 아이의 상태가 나아진 정도에 대한 설문 결과를 보면 아주 좋아졌다 $25 \%(\mathrm{n}=8)$, 약간 좋아졌다 $50 \%$ $(\mathrm{n}=16)$, 변화 없다 $25 \%(\mathrm{n}=8)$ 로 상태가 나빠졌다는 의견은 없 었다. 관심군 부모의 변화된 점을 보면, 양육태도 수정 노력 $43.8 \%(\mathrm{n}=14)$, 정신건강 문제 인지 $34.4 \%(\mathrm{n}=11)$, 의사소통의 기 회 획득 $9.4 \%(\mathrm{n}=3)$, 변화 없음 $6.3 \%(\mathrm{n}=2)$, 정신건강 문제 개선 $3.1 \%(\mathrm{n}=1)$, 정신건강 관리에 대한 두려움 감소 $3.1 \%(\mathrm{n}=1)$ 였다. 관심군에서 학생정서-행동특성검사 참여 이후 가장 큰 변화 는 부모가 정서·행동 문제에 관심을 갖게 되었다 $(78.1 \%$, $\mathrm{n}=25$ )가 압도적으로 많았다. 그리고 순차적으로 아이의 정 서·행동 문제 개선 $9.4 \%(\mathrm{n}=3)$, 학교에서의 관심도 증가 $6.3 \%$ $(\mathrm{n}=2)$, 정신건강 문제에 대한 인식 개선 $3.1 \%(\mathrm{n}=1)$, 전문적인 치료 시작 $3.1 \%(\mathrm{n}=1)$ 순으로 확인되었다. 관심군 도움에서의 보완점으로는 관심군 대상자라는 낙인에 대한 염려 $28.1 \%(\mathrm{n}=9)$, 다양한 서비스의 부족 $21.9 \%(\mathrm{n}=7)$, 환경의 열악 $15.6 \%(\mathrm{n}=5)$, 보완 사항 없음 $15.6 \%(n=5)$, 도움까지 긴 대기시간 $9.4 \%(n=3)$, 기타 의견 $9.4 \%(\mathrm{n}=3)$ 였다.

\section{고 찰}

연구에서 확인된 것을 보면 부모와 교사 집단 모두가 학생정 서·행동특성검사의 필요성과 만족도에 대해서 전반적으로 긍 정적인 평가를 하고 있다는 것을 알 수 있다. 이것은 수년간 시 행된 학생정서-행동특성검사가 어느 정도 자리를 잡아가고 있 고, 인정을 받고 있다는 점을 시사한다. 검사의 필요성에 대해 서는 부모가 교사보다 다소 높은데, 이를 통해서 부모들의 정신 건강에 대한 높아진 관심도를 엿볼 수 있다.

학생정서·행동특성검사의 성과로 부모와 교사 집단 모두 공 통적으로 학생들에 대한 관심 증가 및 상태에 대한 확인을 할 수 있는 점을 꼽았고, 부모는 정신건강 관리의 중요성을 인식 하는 계기가 된 것이 특징이며 교사는 학생의 문제를 조기 발 견할 수 있는 계기가 된 것이 특징이다. 검사를 시행하는 것만 으로도 정신건강에 대한 관심과 중요성을 인식할 수 있는 계 기가 된다는 점을 알 수 있고 이는 선행연구에서 이미 밝혀진 내용과 일치하는 점이다. ${ }^{9}$

보완점에서 부모와 교사 집단 간 차이를 볼 수 있는데, 부모 는 설명의 부족과 학교 내에서의 관리 부족에 대해서 의견을 표현한 반면에 교사는 외부 기관 연계 및 인력 충원에 대해서 의견을 표현했다. 관심군에 대한 사후 관리에서도 부모는 학 교 내에서 담임교사나 보건교사 혹은 상담교사 등을 통해서 도움을 받는 것을 원하는 반면에 교사는 외부 전문가나 외부 전문기관을 통해서 도움을 받기를 더 희망했다. 이를 종합해 보면 학생들의 정신건강 문제에 대한 접근 및 관리에 있어서 학교 내에서 해결하기를 희망하는 부모들과는 달리 교사는 학생들의 문제가 좀 더 전문적인 접근을 통해 해결되기를 원 하는 것으로 볼 수 있다. 교사의 이러한 요구는 $\mathrm{Ha}$ 등이의 연 구에서 제시된 것처럼 학생 정신건강에 대한 부담을 더 이상 교사에게만 전가하는 것이 아니라, 적절한 정신건강 자원과 연계를 통해 적극적으로 지원함으로써, 교사의 역량을 높이 고 보다 효과적으로 대처해 나갈 수 있도록 해야 한다는 것과 그 맥락을 같이 할 수 있다.

학생정서-행동특성검사 시행 여부에 대해서 인지한 부모가 교사보다 낮고, 부모가 보완점에서 검사 안내 및 결과에 대한 설명이 부족한 점을 우선으로 꼽은 것은 주목해야 할 점이다. 이는 부모가 자녀의 정신건강 문제에 대해 어떤 인식을 가지 고 있는지에 따라 치료연계율이 달라질 수 있다는 점 ${ }^{11}$ 에서 부모 대상으로 검사에 대한 홍보와 설명이 더욱 필요한 것으 로 볼 수 있다. 더욱이 관심군 학생을 지원하는 데 가장 큰 어 려움은 학부모가 서비스를 거부하거나 비협조적인 경우이고," 서구의 경우에도 학교 기반 정신건강 사업의 가장 큰 장애물 중 하나가 부모의 동의라는 점을 고려할 때, ${ }^{12)}$ 부모의 인식 개 
선 및 참여에 적극적인 전략이 필요하다.

사후관리 측면을 보면 부모가 사후 도움에 대한 만족도가 더욱 낮은데, 이는 부모 입장에서 검사만 시행하고 학생들에 게 사후 조치가 미흡하다고 생각하는 것으로 볼 수 있다. 또 한 부모는 교사보다 검사에 대한 비밀 엄수가 부족하다고 생 각하는데 이는 관심군 관리에서 보이는 것처럼 부모 입장에 서 검사 결과가 알려짐으로 인해서 낙인과 같이 자녀에게 불이 익이 되지 않을까 하는 걱정을 엿볼 수 있다. 이는 Owens 등 ${ }^{13)}$ 의 연구에서 아동의 문제 행동에 대한 정신건강 서비스로의 유입을 방해하는 요인을 크게 3가지로 나눈 것 중 하나인 정 신건강 서비스에 대한 불신 내지 부정적 경험 같은 편견과 정 신병자라는 낙인이 찍힐지 모른다는 치료에 대한 저항과 연결 고리를 찾을 수 있다. 한편 부모보다 교사가 학생들의 정서, 행 동적 문제의 정도를 높다고 생각하는데 이는 정신건강 이해력 에 대한 연구에서 교사의 문제 인식률이 부모보다 높다고 보 고된 것과 일치하는 결과이다. ${ }^{14)}$ 집에서는 문제가 되지 않을 수도 있는 학생들의 행동이 학교 단체 생활에서 규칙과 규율 을 따르면서는 문제가 될 수 있다는 점이 이러한 차이를 만들 었다고 볼 수 있다.

관심군 관리에 대한 부모의 반응을 보면 전반적인 만족도 도 높고, 도움을 받고 나서 호전된 경과를 보고하는 경우가 높았다. 그리고 관리 성과에 대해서도 인정을 하고 있고 부모 가 학생의 정서-행동문제를 알고 관심을 갖게 되고 양육태도 에 대한 변화를 유도하는 점은 긍정적인 효과로 볼 수 있다.

본 연구의 제한점은 우선 본 연구에 시행된 설문지는 표준 화, 정량화된 척도가 아니라는 것이다. 그리고 초기 설문 대상 으로 설정된 인원에 비해서 실제 응답률이 매우 낮은데, 이를 사전에 예상하고 초기 설문 대상의 인원수를 충분히 설정했다. 그러나 교사에 비해서 현저히 낮은 부모의 응답률은 부모 대상 으로의 홍보 및 설명이 더욱 필요했던 점으로 볼 수 있다. 추 후 학년별로 비교할 수 있을 만큼의 충분한 인원수가 모집이 된다면 학년별로 의미 있는 인식의 차이를 확인할 수 있을 것 으로 기대된다. 또한 지역협력모델에 참여한 학교에서 학생정 서-행동특성검사의 인식도와 성과를 조사한 것으로 검사 자 체의 성과인지 지역협력모델 사업의 성과인지 엄밀하게 구별 하기가 어렵다. 그리고 정신건강 고위험군에 대해서 효과적으 로 선별하는지에 대한 평가를 위해서는 검사 도구의 민감도 와 특이도에 대한 추가적인 연구가 필요하다. 마지막으로 학 생정서·행동특성검사는 지역에 따른 편차가 높아 이에 대한 인식의 차이로 인한 일반화가 어렵다는 점을 제한점으로 볼 수 있다.

\section{결 론}

부모와 교사는 학생정서-행동특성검사에 대해 그 필요성을 충분히 인식하고 있었으며, 대체로 신뢰도와 만족도가 높은 검사로 인식하였다. 부모의 인식에 있어 학생정서·행동특성 검사에 대한 홍보와 사후 설명이 충분히 이뤄지지 않은 것으 로 보여 이에 대한 보완이 필요할 것으로 보인다. 또한 전문적 인 도움이 필요한 학생들의 효율적인 연계를 위한 교사들의 체 계적인 지침과 교육과정 또한 필요할 것이다. 향후 본 연구결 과가 학생정서·행동특성검사를 더욱 체계적으로 시행할 수 있는 자료로 사용되기를 기대한다.

중심 단어: 학생 건강 서비스; 정신건강; 개인적인 만족; 조사와 설문지.

\section{Acknowledgments}

본 연구는 2012년 정부(교육부)의 재원으로 한국연구재단의 지원 을 받아 수행된 연구임(NRF-2012S1A5B8A02045006).

\section{Conflicts of Interest}

The authors have no financial conflicts of interest.

\section{REFERENCES}

1) World Health Organization. Report on health for the world's adolescents 2014 [cited 2017 Aug 7]. Available from: http://apps.who. int/adolescent/second-decade/files/1612_MNCAH_HWA_Executive_Summary.pdf.

2) Korean National Statistical Office. Annual report on the cause of death statistics 2015 [cited 2017 Aug 7]. Available from: http://kostat.go.kr/portal/korea/kor_nw/2/6/2/index.board.

3) Ministry of health and welfare. Annual report on Korea youth risk behavior web-based survey 2016 [cited 2017 Aug 7]. Available from: http://kosis.kr/statisticsList/statisticsList_01List.jsp?vwcd=MT_ ZTITLE\&parmTabId=M_01_01\#SubCont.

4) Ahn DH. Mental disorders in adolescents. J Korean Med Assoc 2009;52:745-757.

5) Hong HJ, No BR, Kwon HI, Kim HK, Kim YR, Woo JJ. A study on the role of national hospitals to promote mental health of children and adolescents in the community. Ministry of Health and Welfare 2013.

6) Huh Y, Ahn DH, Choi JH, Kang JY, Kim YY, Oh KJ. Development of a child problem-behavior screening test. J Korean Neuropsychiatr Assoc 2003;42:724-735.

7) Jung SA, Ahn DH, Chung SY, Jeong YG, Kim YY. Development of screening test for adolescent mental health and problem behavior. J Korean Neuropsychiatr Assoc 2008;47:168-176.

8) Bhang SY, Yoo HK, Kim JH, Kim B, Bahn GH, Ahn D, et al. Revision of adolescent mental health and problem behavior screening questionnaire: development of adolescent mental health and problem behavior screening questionnaire-II. J Korean Acad Child Adolesc Psychiatry 2011;22:271-286.

9) Kim JA, Ha KH, Hong HJ, Kim HY. 2013 Students' mental health school-community cooperative model: management of high risk students and change in awareness of mental health in school. J Korean Acad Child Adolesc Psychiatry 2015;26:94-103.

10) Ha KH, Kim JA, Kim WS, Hong HJ, Kim SY. The effect of students' mental health school-community cooperative model on the 
school mental health awareness. J Korean Acad Child Adolesc Psychiatry 2016;27:100-108.

11) Kim HJ, Cho SC, Kim JW, Kang JW, Shin MS, Kim HW, et al. The effectiveness of mental health problems screening and treatment linkage in children \& adolescents: community based study focused on ADHD and depression. J Korean Acad Child Adolesc Psychiatry 2009;20:129-139.

12) Langley AK, Nadeem E, Kataoka SH, Stein BD, Jaycox LH. Evidence-based mental health programs in schools: barriers and facili- tators of successful implementation. School Ment Health 2010;2: 105-113.

13) Owens PL, Hoagwood K, Horwitz SM, Leaf PJ, Poduska JM, Kellam SG, et al. Barriers to children's mental health services. J Am Acad Child Adolesc Psychiatry 2002;41:731-738.

14) Ko H, Choi H. Mental health literacy among parents of adolescents and teachers in Korea. J Korean Acad Psychiatr Ment Health Nurs 2015;24:168-177. 